\title{
The Effect of Internal Factor and External Factor towards Beta and Stocks Returns in the Real Estate Company in Indonesia Stock Exchange
}

\author{
Catur Kumala Dewi ${ }^{\# 1}$, Rina Masithoh $\mathrm{H}^{\# 2}$ \\ \#University of 17 August 1945 \\ Samarinda, Indonesia \\ ${ }^{1}$ caturkdeyahoo.com \\ ${ }^{2}$ rina.masithoh@yahoo.com
}

\begin{abstract}
This research was done with the aim to test and analyze internal and external factors regarding beta and return stock. The internal factors are Dividend Payout Ratio, Asset Growth, Debt to Equity Ratio, Current Asset, Asset Size, Price Earnings Ratio and Return on Asset. Whereas the external factors are inflation, interest rate and exchange rate. Statistic tool which was used to support the calculation is Amos, namely using SEM (Structural Equation Model). The samples used were 21 real estate companies, while samples selection used purposive sampling method. The research was carried out with 105 data from 2008 to 2012. The result of the research showed that internal factors are directly and significantly influence beta stocks, external factors are neither directly nor significantly influence beta stock, internal factors are neither directly nor significantly influence return stocks, external factors are neither directly nor significantly influence return stock, beta stock are directly and significantly influence return stocks, internal factors are not affect directly to stock return through beta stock and external factors are neither directly nor significantly influence stock return through beta stock.
\end{abstract}

Keywords - beta, stock return, financial performance, inflation, exchange rates, interest rates

\section{INTRODUCTION}

Minimizing risk can be done, but not by avoiding it as described by [5]. Investment in property and real estate is one of long-term investment. One indicator of the growth of a healthy economy is marked by growth in property and real estate.

TABLE 1

GROWTH OF REAL ESTATE STOCK PRICE INDEX 2008-2012

\begin{tabular}{|l|c|c|}
\hline No & Year & $\begin{array}{c}\text { Stock } \\
\text { Price Index }\end{array}$ \\
\hline 1 & 2008 & $11.06 \%$ \\
\hline 2 & 2009 & $2.78 \%$ \\
\hline 3 & 2010 & $6.96 \%$ \\
\hline 4 & 2011 & $3.79 \%$ \\
\hline 5 & 2012 & $4.30 \%$ \\
\hline
\end{tabular}

\section{Source: www.bps.go.id}

Table 1 shows the growth of real estate stock price index from 2008-2012. In 2008 saw a significant decline due to the economic conditions of Indonesia hit by the economic crisis. Along with the better economic growth, there is an increase in stock price index starting to 2009 until 2012.

The portfolio is a collection of many securities traded on the stock exchange [25]. Beta is a measure of the volatility of return, whereas volatility itself is the fluctuation of the returns of a securities or portfolio within a certain period of time. [14]

Table II shows the average inflation rate from 2008 to 2012. It appears that inflation is very high there in 2008 of $11.06 \%$, finally declining and staying at $4.30 \%$ until 2012 . The inflation spikes in 2008 because of the monetary crisis that hit Indonesia to catapult prices of goods and services. It consequently will reduce purchasing power and indirectly affect the capital market.

TABLE II

AVERAGE INFLATION RATE FROM 2008 TO 2012

\begin{tabular}{|c|c|}
\hline Year & $\begin{array}{c}\text { Average } \\
\text { Inflation }\end{array}$ \\
\hline 2008 & 11.06 \\
\hline 2009 & 2.78 \\
\hline 2010 & 6.96 \\
\hline 2011 & 3.79 \\
\hline 2012 & 4.30 \\
\hline
\end{tabular}

Source: http://www.bps.id

It is important to involve external factors in order to make a more accurate analysis. External factors can include inflation rate, gross domestic product, interest rate and exchange rate. 


\section{A. Problem Issue}

The importance of estimating the stock beta by using fundamental factors that the results will better illustrate from the stock returns, and then based on the background that has been put forward can be formulated problems as follows:

- Do the internal factors have direct and significant effect on Beta Shares in Real Estate companies in Indonesia Stock Exchange?

- Do the external factors have a direct and significant effect on Beta Shares in Real Estate companies in Indonesia Stock Exchange?

- Do internal factors have a direct and significant effect on Stock Return on Real Estate companies in Indonesia Stock Exchange?

- Do external factors have a direct and significant effect on Stock Returns on Real Estate companies in Indonesia Stock Exchange?

- Do Beta Shares have a direct and significant effect on Stock Return on Real Estate companies in Indonesia Stock Exchange?

- Do internal factors indirectly affect Stock Return through Beta Shares in Real Estate companies in Indonesia Stock Exchange?

- Are external factors indirectly affecting Stock Return through Beta Shares in Real Estate companies in Indonesia Stock Exchange?

\section{GRAND THEORY}

\section{B. Theoretical Basis}

\subsubsection{Shares}

Shares are basically proof of ownership of capital invested in a company. According to [7] shares that are proof of membership of capital ownership will provide profits in the form of dividends or losses.

Stocks that we know there are 2 kinds, namely shares circulating in the stock market [32]:

1. Common stocks

2. Preferred stocks (preferred shares).

\subsubsection{Risk}

Investments made by investors in finance are essentially divided into two, namely direct investment and indirect investment. Investments in shares are included in the category of direct investment. [25] divides risks in 2 types:

1. Systematic risk or called systematic risk.

2. Unsystematic risk

\subsubsection{Beta}

Horne and Wachowiz, Jr. defined risk as a variability of actual return to expected returns [29]. [4] said that volatility is the phase where the ups and downs of prices and price movements. The price here could be the price of everything, but the volatility here is the volatility of the price discussed on the stock market. Generally, price volatility is shaped by factors of production affecting demand and supply.

[4] described historical volatility or also called volatility based on past data. As the name implies, the historical volatility is stock data 12 months ago. If stock prices fluctuate very sharply in the last 12 months, then this stock will enter the category of risk stock. Unfortunately, high volatility stocks can be profitable if investors choose to hold stocks before stock prices reach out a price that can afford them.

[14] said beta is the slope of the slope on the characteristic line, so the beta coefficient can be said to indicate certain characteristics of a security. If Beta $(\beta)$ is equal to one then beta equals market, for Beta $(\beta)>1$ including aggressive, and Beta $(\beta)$ $<1$ including defensive. A beta of 1 indicates that the stock price will move in the market. Beta greater than 1 indicates that stock price volatility exceeds the market. A beta value of less than 1 indicates that the risk is greater than market price volatility.

\subsubsection{Stock Return}

According [14] for short-term investment, accounting beta can be used to predict the risks faced by investors, because the data of past financial performance can give an idea of the return of an investment. In long-term investments, accounting beta does not provide a relevant picture of the returns to be earned. Short-term investments can benefit from following the trend over the previous few years to predict stock volatility a few months later. 
Meanwhile, according to [8] in bearish market condition (downtrend), market return tends to be negative so that bigger beta will result in bigger stock return. In bearish market conditions the resulting market return tends to be positive. As a result, the resulting stock return will be even greater if the stock market beta gets bigger. In this research is suggested when the market conditions are bearish, investing in stocks with lower beta value is preferred. Conversely, in bullish market conditions (uptrend), investors should prefer to invest in stocks with high beta because the resulting return is greater.

\subsubsection{Internal Factors}

These fundamental variables are the variables studied by Beaver, Kettler and Scholes. These variables are accounting variables that are generally related to the beta. The seven variables are as follows:

1. Dividend Payout

2. Asset Growth

3. Leverage

4. Liquidity

5. Asset Size

6. Earning Variability

7. Accounting Beta

\subsubsection{External Factors}

Systematic risk is a systemized risk so it cannot be changed because the systematic risk is influenced by fluctuating economic movement of macro factors. Systematic risks can include inflation, exchange rate fluctuations, interest rate fluctuations, fiscal policy and other policies governing the activity of an investment. This has been revealed by [11] in the February 2011 MRA journal.

1. Inflation

2. Exchange Rate

3. Interest Rate

\subsection{Research Framework}

The framework research is shown as below.

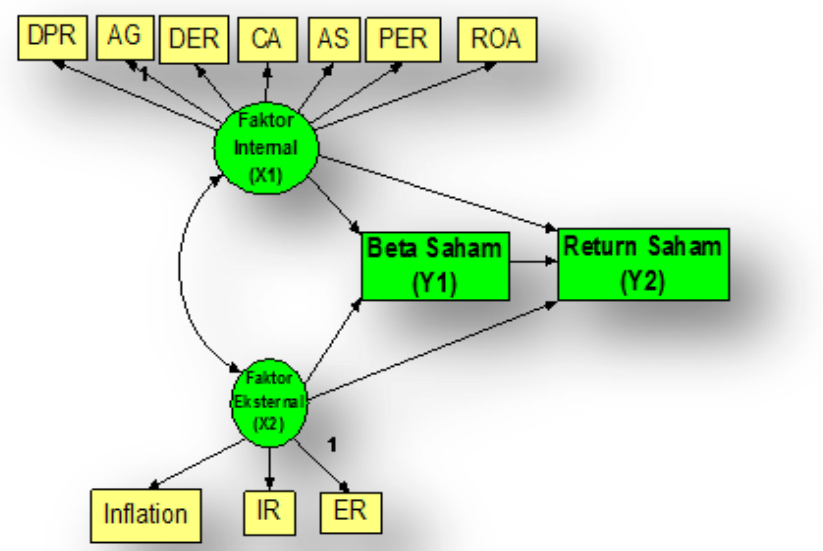

Figure 2.1

Research Framework

Annotation:

Internal Factors $\left(\mathrm{X}_{1}\right)$ :

(1) Dividend Payout Ratio (DPR)

(2) Asset Growth (AG)

(3) Debt to Equity Ratio (DER)

(4) Current Asset (CA)

(5) Asset Size (AS)

(6) Price Earnings Ratio (PER)

(7) Return on Asset (ROA)

External Factor $\left(\mathrm{X}_{2}\right)$ :

(1) Inflation

(2) Interest Rate

(3) Exchange Rate

2.3. Correlation among Research Variable

2.3.1. Internal Factors towards Beta Stocks

According to [34], the analysis of financial ratios is an instrument of company achievement analysis that explains the relationship and financial indicators, to indicate changes in financial condition or achievement in the past, and helps illustrate the trend pattern change, to then show the risks and opportunities attached to company and stock of the company concerned. This shows the effect that arises from the analysis of financial ratios on the risk of shares of the traded company.

\subsubsection{External Factor towards Beta Stocks}

According to [30] resulted in research that macroeconomic factors are external factors 
including inflation, interest rates and exchange rates do not affect the beta stock either simultaneously or partially. These factors are concerned with the selection of external factors to be examined by the author, although research conducted by [30] only examines the macroeconomic factors that affect the beta.

\subsubsection{Internal Factors towards Return Stocks}

Not all financial ratios of each company in the Indonesia Stock Exchange can be a good parameter to predict the change in return of the company. This can be based on research conducted by [8] which resulted in the conclusion that ROA and PER ratios can be used to explain the stock return of manufacturing companies so that this ratio needs to be considered for investors in analyzing company performance, which influence the increase of stock return.

\subsubsection{External Factors towards Return Stocks}

The interest rate affects the stock price at which the rising stock price will affect the stock return. If interest rates rise, then the impact on the increase in interest rates on loans that will lead to interest rates on credit that will burden corporate profits can even lose. Companies experiencing a definite interest rate risk share price of the company will decline as investors judge the company has no good prospects. High interest rates are a negative signal to stock prices [15]

\subsubsection{Beta Stocks towards Returns Stocks}

The fundamental reason for the beta effect of stocks on stock returns is because systematic risk cannot be eliminated by forming a portfolio in an investment. Therefore, for an investor the risk becomes more relevant to be considered in choosing a combination of shares in the portfolio it creates. This is in accordance with the concept of Markowitz who said that any risk will affect the stock return so that companies need to make a portfolio of shares by minimizing risk and maximizing profit [37].

\subsection{Hypothesis}

Based on theoretical studies and empirical studies and conceptual frameworks that have been put forward before, it can be arranged research hypothesis as follows:

1.Internal factors are directly and significantly influence beta stocks in Real Estate companies in Indonesia Stock Exchange.

2. External factors are directly and significantly influence beta stocks in Real Estate companies in Indonesia Stock Exchange.

3. Internal factors are directly and significantly influence returns of stocks in Real Estate companies in Indonesia Stock Exchange.

4. External factors are directly and significantly influence return of stock in Real Estate companies in Indonesia Stock Exchange.

5. Beta stocks are directly and significantly influence return of stocks Real Estate companies in Indonesia Stock Exchange.

6. Internal factors are directly and significantly influence return of stocks through Beta Stock in Real Estate companies in Indonesia Stock Exchange.

7. External factors are directly and significantly influence return of stocks through Beta stocks in Real Estate companies in Indonesia Stock Exchange.

\section{RESEARCH METHOD}

\subsection{Research Plan}

The research design is to test and analyze X1 (internal factors) that have seven indicators, they are:

1. Dividend Payout Ratio $\left(\mathrm{X}_{11}\right)$

2. Asset Growth $\left(\mathrm{X}_{12}\right)$

3. Debt to Equity Ratio $\left(\mathrm{X}_{13}\right)$

4. Current Asset $\left(\mathrm{X}_{14}\right)$

5. Asset Size $\left(\mathrm{X}_{15}\right)$

6. Price Earnings Ratio $\left(\mathrm{X}_{16}\right)$

7. Return on Asset $\left(X_{17}\right)$

In addition to internal factors, the authors add external factors. External factors are represented by $\mathrm{X} 2$. External factors involve:

1. Inflation rate $\left(\mathrm{X}_{21}\right)$

2. Interest rate $\left(X_{22}\right)$

3. Interest rate $\left(\mathrm{X}_{23}\right)$

\subsection{Operational Definition}

Table 3.1 
Operational Definition

\begin{tabular}{|c|c|c|c|}
\hline No & Variable & $\begin{array}{l}\text { Operational } \\
\text { Definition }\end{array}$ & \\
\hline \multirow[t]{2}{*}{1} & Dividend & Dividend & Dividend per shares \\
\hline & Payout & $\begin{array}{l}\text { payout ratio is a } \\
\text { measure of } \\
\text { dividend per } \\
\text { shares divided by } \\
\text { earning per shares }\end{array}$ & $\overline{\text { Eaming per shares }}$ \\
\hline \multirow[t]{2}{*}{2} & Asset growth & Asset growth is a & Assets $_{\mathrm{it}}-$ Assets $_{\mathrm{it}-1}$ \\
\hline & & $\begin{array}{l}\text { ratios to scale the } \\
\text { ability of } \\
\text { company to gain } \\
\text { profit }\end{array}$ & Assets $_{\mathrm{it}-1}$ \\
\hline \multirow[t]{2}{*}{3} & Leverage & Measured by debt & Total Liabilities \\
\hline & & to equity ratio & Total Equity \\
\hline \multirow[t]{2}{*}{4} & Liquidity & Liquidity is & Current asset \\
\hline & & $\begin{array}{l}\text { measured from } \\
\text { current asset }\end{array}$ & $\overline{\text { Current Liabilities }}$ \\
\hline 5 & Asset size & $\begin{array}{l}\text { Measured by asset } \\
\text { size }\end{array}$ & Total Asset \\
\hline \multirow[t]{2}{*}{6} & Earning & Measured from & Stock Price \\
\hline & variability & PER & EPS \\
\hline 7 & Accounting beta & $\begin{array}{l}\text { The sensitivity of } \\
\text { ROA }\end{array}$ & $\frac{\text { Net Income }}{\text { Total Asset }}$ \\
\hline \multirow[t]{2}{*}{8} & Beta Stocks & Volatility & Cov (Ri. Rm) \\
\hline & & meas & $\operatorname{Var}(\mathrm{Rm})$ \\
\hline 9 & Return Stocks & $\begin{array}{l}\text { The measure used } \\
\text { in is capital } \\
\text { gain/loss }\end{array}$ & $\frac{\mathrm{Pt}-(\mathrm{Pt}-1)}{(\mathrm{Pt}-1)}$ \\
\hline 10 & Inflation & $\begin{array}{lr}\text { The annual } \\
\text { inflation rate } \\
\text { issued by BI }\end{array}$ & - \\
\hline 11 & Interest Rate & $\begin{array}{l}\text { Average annual } \\
\text { SBI }\end{array}$ & - \\
\hline 12 & Exchange Rate & $\begin{array}{l}\text { Middle rate of } \\
\text { exchange rate at } \\
\text { BI }\end{array}$ & - \\
\hline
\end{tabular}

Source: Researcher

\subsection{Population and Sample}

The population of this research is Property \& Real Estate company listed in Indonesia Stock Exchange with sample selection using purposive sampling method, with the following criteria:

1. Shares of listed real estate companies listed on the Indonesia Stock Exchange (BEI) for five years from 2008 to 2012.

2. Listed Real Estate Companies issuing financial statements for the period 2008 to 2012 and posted in ICMD (Indonesia Capital Market Directory) and published.

3. Real Estate Companies that do not delist and liquidate during 2008 to 2102 .

4. Data is available for analysis.

\subsection{Data Source}

The available data is sorted according to the research needs. The data is in the form of financial statements of Real Estate companies or property areas where there are limits to the data used. Sources of other supporting data, obtained from Yahoo! Finance and websites that support this research. The data used during the period of 5 (five) years, example from 2008 to 2012. Data from ICMD and other supporting data can be used as benchmark data for other researchers in accordance with each of the variables studied, as well as from IDX (Indonesia Stock Exchange).

\subsection{Data Analysis}

The statistical calculations that can be used in this study are as follows:

\subsubsection{SEM Assumption}

In this research the processing is done with AMOS. With the number of samples in this study> 100 then the selected analytical technique is Structural Equation Model (SEM). [17] quotes Ghozali said there are some requirements or assumptions that must be met by research data prior to processing with SEM, among others:

1. Test the sample size

The sample size that must be met in this model is a minimum of 100 and above $(<100)$

2. Data Normality Test

The data distribution is said to be normal at a 0.01 significance level if the Critical Ratio (CR), skeweness, or CR kurtosis (tapers) are no more than \pm 2.58 .

\section{Test Outliers}

Outliers are observations that appear with extreme values because of the combination of unique characteristics it possesses that look very much different from other observations.

4. Multicolinearity Test

If the correlation between exogenous constructs $<0.85$ means no multicollinearity occurs.

Basically SEM is a combination of factor analysis, multiple regression analysis, and correlation. Some Goodness-of-Fit Indexes and cutoff values can be used to test the feasibility of a model in Table 3.2 below: 
TABLE III

GOODNESS OF FIT CRITERIA

\begin{tabular}{|l|l|}
\hline Criteria Index Size & Reverence Value \\
\hline Kai Kuadrat $\left(\mathrm{X}^{2}\right)$ & Smallest \\
\hline $\mathrm{p}$-value & $\geq 0,05$ \\
\hline CMIN/df & $\leq 2,00$ \\
\hline RMSEA & $\leq 0,08$ \\
\hline GFI & Approaches 1 \\
\hline AGFI & Approaches 1 \\
\hline TLI & Approaches 1 \\
\hline CFI & Approaches 1 \\
\hline
\end{tabular}

Source: Statistical Guidence for SEM \& PLS with SPSS AMOS

The basic considerations of using SEM are:

1. Variable $X_{1}$ is internal factor which is consisting of 7 variables

2. Variable $\mathrm{X}_{2}$ is External factors

3. Variable of $Y_{1}$ is beta stocks and variable from $\mathrm{Y}_{2}$ is return stocks

4. The amount of data generated from $X_{1}, X_{2}, Y_{1}$ and $Y_{2}$ with the number of sample of 21 companies for 5 years all amounted to 105 data, where one of the requirements of SEM usage is with the data amounted to $<100$.

Structure Equation Model (SEM) in the research is used to know the direct influence and indirect influence between the variables studied. The Structure Equation Model (SEM) scheme in this research is shown in Figure 3.1 below:

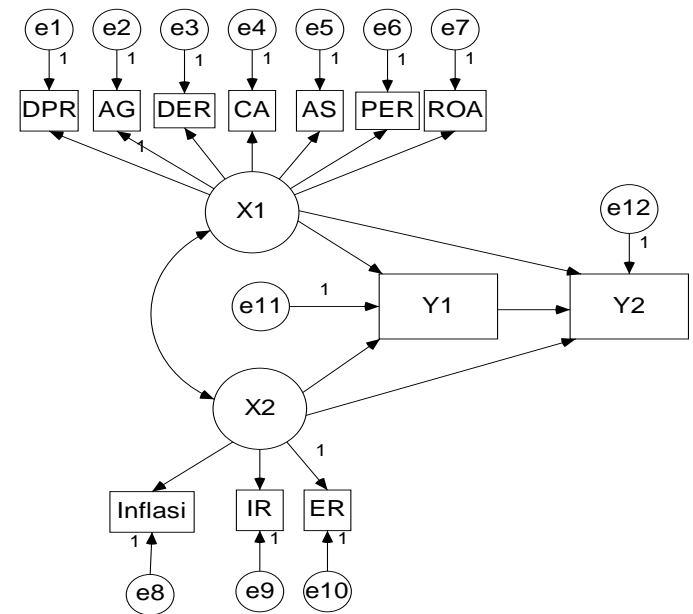

Figure 3.1.

Framework Concept
Variables as show bellow:

$\begin{array}{ll}\text { DPR } & \text { : Dividend Payout } \\ \text { AG } & \text { : Asset Growth } \\ \text { DER } & \text { : Debt to Equity Ratio } \\ \text { CA } & \text { : Current Asset } \\ \text { AS } & \text { : Asset Size } \\ \text { PER } & \text { : Price Earnings Ratio } \\ \text { ROA } & \text { : Return on Asset } \\ \text { Inflation } & \text { : Inflation } \\ \text { IR } & \text { : Interest Rate } \\ \text { ER } & \text { : Exchange Rate }\end{array}$

\section{IV.RESEARCH OBJECT DESCRIPTION}

A. Research Object

The companies studied are presented in Table 4.1 along with the Initial Public Offering (IPO) time.

TABLE IV RESEARCH OBJECTS

\begin{tabular}{|c|c|c|c|}
\hline No & Code & $\begin{array}{l}\text { Company } \\
\text { Name }\end{array}$ & $\begin{array}{l}\text { Initial Public } \\
\text { Offering (IPO) }\end{array}$ \\
\hline 1 & BIPP & $\begin{array}{l}\text { Bhuwanatala } \\
\text { Indah Permai } \\
\text { Tbk. }\end{array}$ & 23 October1995 \\
\hline 2 & CTRA & $\begin{array}{l}\text { Ciputra } \\
\text { Development } \\
\text { Tbk. }\end{array}$ & 28 May 1994 \\
\hline 3 & CTRS & $\begin{array}{l}\text { Ciputra Surya } \\
\text { Tbk. }\end{array}$ & 15 January 1999 \\
\hline 4 & DART & $\begin{array}{l}\text { Duta Anggada } \\
\text { Realty Tbk. }\end{array}$ & 8 May 1990 \\
\hline 5 & DILD & $\begin{array}{l}\text { Intiland } \\
\text { Development } \\
\text { Tbk. }\end{array}$ & 4 September 1991 \\
\hline 6 & DUTI & $\begin{array}{l}\text { Duta Pertiwi } \\
\text { Tbk. }\end{array}$ & 2 November 1994 \\
\hline 7 & ELTY & $\begin{array}{l}\text { Bakrieland } \\
\text { Development }\end{array}$ & 30 October 1995 \\
\hline 8 & GMTD & $\begin{array}{l}\text { Gowa } \\
\text { Makassar } \\
\text { Tourism } \\
\text { Development } \\
\text { Tbk. }\end{array}$ & 11 December 2000 \\
\hline 9 & JIHD & $\begin{array}{l}\text { Jakarta } \\
\text { International } \\
\text { Hotel \& Dev. } \\
\text { Tbk. }\end{array}$ & 29 February 1984 \\
\hline $0^{1}$ & KIJA & $\begin{array}{l}\text { Kawasan } \\
\text { Industri } \\
\text { Jababeka }\end{array}$ & 10 January 1995 \\
\hline
\end{tabular}


TABLE IV, CONT.

\begin{tabular}{|c|c|c|c|}
\hline $\begin{array}{ll} & 1 \\
& \end{array}$ & KPIG & $\begin{array}{l}\text { Global Land } \\
\text { Development } \\
\text { Tbk. }\end{array}$ & 30 March 2000 \\
\hline $2^{1}$ & LPCK & $\begin{array}{l}\text { Lippo } \\
\text { Cikarang Tbk. }\end{array}$ & 24 July 1997 \\
\hline $3^{1}$ & MDLN & $\begin{array}{l}\text { Modernland } \\
\text { Realty Tbk. }\end{array}$ & 18 January 1993 \\
\hline $4^{1}$ & MTSM & $\begin{array}{l}\text { Metro Realty } \\
\text { Tbk. }\end{array}$ & 8 November 1992 \\
\hline $5^{1}$ & OMRE & $\begin{array}{l}\text { Indonesia } \\
\text { Prima Property } \\
\text { Tbk. }\end{array}$ & 22 August 1994 \\
\hline $6^{1}$ & RBMS & $\begin{array}{l}\text { Ristia Bintang } \\
\text { Mahkotasejati } \\
\text { Tbk. }\end{array}$ & 19 December 1997 \\
\hline $\begin{array}{ll}7 & 1\end{array}$ & RDTX & $\begin{array}{l}\text { Roda } \text { Vivatex } \\
\text { Tbk. }\end{array}$ & 14 May 1990 \\
\hline $\begin{array}{ll} & 1 \\
& \end{array}$ & SMDM & $\begin{array}{l}\text { Suryamas } \\
\text { Dutamakmur } \\
\text { Tbk. }\end{array}$ & 12 October 1995 \\
\hline $\begin{array}{ll} & 1 \\
\end{array}$ & SMRA & $\begin{array}{l}\text { Summarecon } \\
\text { Agung Tbk. }\end{array}$ & 7 May 1990 \\
\hline $0^{2}$ & ADHI & $\begin{array}{ll}\text { Adhi } & \text { Karya } \\
\text { (Persero) Tbk. }\end{array}$ & 18 March 2004 \\
\hline 12 & SSIA & $\begin{array}{l}\text { Suya Semesta } \\
\text { Internusa Tbk. }\end{array}$ & 27 March 1997 \\
\hline
\end{tabular}

\section{ANALYSIS AND DISCUSSION}

A. Analysis

Based on data that has been recorded in the research, then the next step is analyzing data with AMOS package program as follows:

TABLE V

RECAP CALCULATION

\begin{tabular}{|lc|c|c|l|}
\hline \multicolumn{7}{|c}{ C.R. } & $\mathbf{P}$ & Influence & Outcome \\
\hline ZBS & 3.668 & $* * *$ & 0.553 & Significant \\
\hline ZBS & - & & & Not \\
ZDPR & 0.174 & 0.862 & -0.012 & Significant \\
\hline ZAG & 2.34 & 0.019 & 0.251 & Significant \\
\hline ZDER & 3.101 & 0.002 & 0.386 & Significant \\
\hline ZCA & 4.131 & $* * *$ & 1.041 & Significant \\
\hline ZAS & 4.137 & $* * *$ & 0.838 & Significant \\
\hline & & & & $\begin{array}{l}\text { Not } \\
\text { ZPER }\end{array}$ \\
\hline & 0.901 & 0.367 & 0.085 & Significant \\
ZROA & 1.291 & 0.197 & 0.125 & $\begin{array}{l}\text { Not } \\
\text { Significant }\end{array}$ \\
\hline ZER & & & 0.416 & \\
\hline ZIR & 4.598 & $* * *$ & 0.639 & Significant \\
\hline $\begin{array}{l}\text { Z- } \\
\text { Inflation }\end{array}$ & 3.197 & 0.001 & 1.123 & Significant \\
\hline
\end{tabular}

TABLE V, CONT.

TABLE V, CONT.
\begin{tabular}{|cc|c|c|l|}
\hline ZRS & 14.86 & $* * *$ & 0.910 & Significant \\
\hline & - & & & Not \\
ZRS & 1.917 & 0.055 & -0.124 & Significant \\
\hline & & & & Not \\
ZRS & 1.601 & 0.109 & 0.075 & Significant \\
\hline
\end{tabular}

Source: AMOS Output

So it can be inferred from the hypothesis that:

1. Internal factors have a direct and significant effect on Beta Share.

2. External factors have no direct and insignificant effect on Stock Beta.

3. Internal factors have no direct and insignificant effect on Stock Return.

4. External factors have no direct and insignificant effect on Stock Return.

5. Beta Shares have a direct and significant effect on Stock Return.

6. Internal factors indirectly have no effect on Stock Return through Beta Share.

7. External Factors indirectly affect and not significant to the Stock Return through Beta Shares.

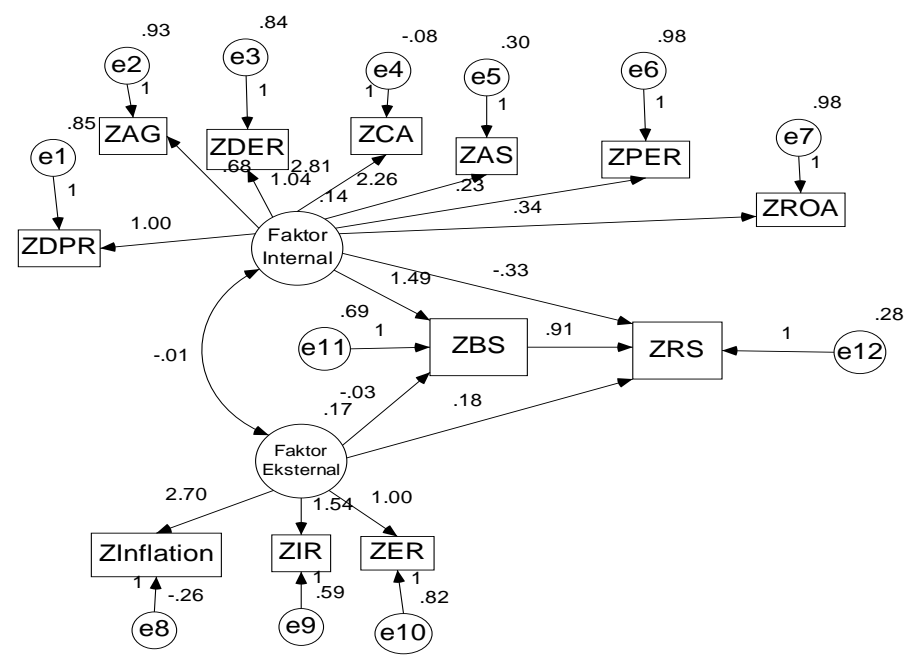

Figure 5.1

SEM's Output

\section{B. Discussion}

\subsubsection{Hyphotesis Test for Internal Factor towards} Beta Stocks

The variable $\mathrm{X} 1$ which is the internal variable as a whole has a significant effect. The most significant influence among the seven variables studied from X1 is the ZCA variable and the ZAS variable whose $\mathrm{P}$ value is represented by an asterisk 
means that the relationship is very strong to close to $100 \%$ or more.

The results of the previous discussion show that hypothesis 1 which identifying that internal factors have a direct and significant effect on the beta stocks on real estate company in Indonesia Stock Exchange is acceptable.

\subsubsection{Hypothesis Test for External Factors towards Beta Stocks}

Overall, external factors are not significant effect on the stock beta. Beta stock is an unavoidable risk, while external factors from this research are one factor of risk that can be avoided, so this can theoretically be accepted. If the risk can be avoided, then the hypothesis of no significance of influence between external factors and stock beta could happen. This is in line with research conducted by [4] that produces a negative influence of inflation.

The influence of external factors is significant and the most significant variables are inflation and interest rate. High inflation boosted prices of goods and services that resulted in influencing government policies to raise interest rates.

The results of the previous discussion show that hypothesis 2 that sounded external factors have a direct and significant effect on the stock beta on real estate companies is unacceptable.

\subsubsection{Hypothesis Test for Internal Factors Towards Returns Stocks \\ The results of previous discussion show that hypothesis 3 which reads internal factors have a direct and significant effect on stock returns on real estate companies is unacceptable.}

\subsubsection{Hyphothesis Test for External Factors towards Return Stocks \\ Based on the previous discussion, it shows hypothesis 4 which reads external factor has a direct and significant effect to stock return on real estate company in Indonesia Stock Exchange is unacceptable.}

\subsubsection{Hyphotesis Test for Beta Stocks towards Return Stocks \\ The results of previous discussion show that hypothesis 5 which reads beta share have direct and}

significant effect to stock return on real estate company in Indonesia Stock Exchange is acceptable.

\subsubsection{Hyphotesis Test for Internal Factors Indirectly through Return Stocks towards Beta Stocks \\ The results of previous discussion show that} hypothesis 6 which reads internal factors have an indirect and significant effect on stock return through beta shares in real estate company in Indonesian Stock Exchange can be accepted.

\subsubsection{Hyphotesis Test for External Factor Indirectly} through Returns Stocks towards Beta Stocks

The results of previous discussion show that hypothesis 7 that reads external factors have an indirect and significant effect on stock return through beta shares in real estate company in Indonesia Stock Exchange is unacceptable.

\section{VI.CONCLUSION}

\section{A. Conclusion}

The conclusions are as follows:

1. Internal factors have a direct and significant effect on Beta Share. Among the internal variables, the most significant are ZDPR, ZCA and ZAS. Internal factors are fundamental factors that are closely related to the financial performance of real estate companies.

2. External factors directly have no effect and not significant on Beta Shares with the value $\mathrm{P}=$ 0.862 where the requirement is significant if the value of $\mathrm{P}<5 \%$. It means that external factors in the form of inflation, interest rates and exchange rates directly have no effect.

3. Internal factors directly have no effect and not significant on the Return of Shares with the value $P>0.05$. Internal factors are not significant effect on stock returns.

4. External factors directly have no effect and not significant on the Return of Shares with the value $\mathrm{P}>0.05$.

5. Beta Shares directly affect and significant to Return Shares with significant probability in all Level Of Confident. 
6. Internal factors indirectly affect the Stock Return through Beta Shares with a value of 0.50 .0 .503 or $50.3 \%$.

7. Eternal Factors indirectly does not affect the Stock Return through Beta Shares with the value obtained -0.11 .

B. Advises

Suggestions given based on the previous conclusions, including:

1. Improving financial performance so that the calculation of financial ratios as a measure of performance increased

2. Taking into account external factors that are not significant to the stock beta, because the change of this factor is unpredictable, so it could be in the following year those factors affect the beta.

3. With internal factors that do not affect the stock return, internal factors should not necessarily be ignored because only a small part of the financial ratios used in research.

4. With respect to external factors that do not affect the stock return, it is necessary to add other external factors such as economic growth, capital flows, central bank independence and political risks.

The indirect relationship between internal factors to stock return through stock beta gives a significant picture between beta and stock return so it is necessary to do indirect research.

\section{REFERENCES}

[1] Ahmad, Kamaruddin. (2004). Dasar-dasar Manajemen Investasi dan Portofolio. Jakarta: Rineka Cipta.

[2] Amadeo, Kimberly. (2012). Volatility. 'http://useeconomy.about.com Diakses 07 November 2013.

[3] Anire, Yance dan Lina Nur Hidayati. (2013). Analisis Pengaruh Inflasi, Tingkat Suku Bunga dan Nilai Tukar Rupiah terhadap Return Saham (Studi Kasus pada Perusahaan Manufaktur yang Terdaftar di Bursa Efek Indonesia. (Online) Vol. 2 Edisi II. https://journal.student.uny.ac.id. Diakses 17 Desember 2013.

[4] Arista, Desy. (2012). Analisis Faktor-faktor yang Mempengaruhi Return Saham (Kasus pada Perusahaan Manufaktur yang Go Public di BEI periode tahun 2005-2009). Jurnal Ilmu Manajemen dan Akuntansi Terapan, Vol. 3 No. 1 Mei 2012.

[5] Buku Pedoman Penulisan Tesis. (2013). Samarinda: Magister Manajemen Universitas Mulawarman.

[6] Bodie, Zvi, Alex Kane dan Alan J. Marcus. (2008). Investasi. Jakarta: Salemba Empat.

[7] Fahmi, Hadi, Yovi Lavianti Hadi. (2009). Teori Portofolio dan Analisis Investasi, Teori dan Soal Jawab. Bandung: Alfabeta.

[8] Farkhan dan Ika. (2012). Pengaruh Rasio Keuangan terhadap Return Saham Perusahaan Manufaktur di BEI. (Online) Vol. 9, 1 September 2012. Diakses 21 Februari 2014.
[9] Harahap, Sofyan Syafri. (2013). Analisis Kritis atas Laporan Keuangan. Jakarta: PT Raja Grafindo Persada.

[10] Haryanto, Dedi dan Riyatno. (2007). Pengaruh Suku Bunga Sertifikat Bank Indonesia dan Nilai Kurs Terhadap Risiko Sistematik Saham Perusahaan di BEJ. Jurnal Keuangan dan Bisnis Vol. 5 No. 1 hal 24-40

[11] Hatta, Atika Jauharia, Bambang Sugeng Dwiyanto. (2009). The Company Fundamental Factors and Systematic Risk in Increasing Stock Price. Vol. 15 No. 2 August 2012, 245-256.

[12] Husnan, Suad. (2005). Dasar-dasar Teori Portofolio dan Analisis Sekuritas. Yogyakarta: AMP YKPN.

[13] Indra, A. Zubaidi. (2006). Faktor-faktor Fundamental Keuangan yang Mempengaruhi Risiko Saham. Jurnal JBM Vol. 2 No. 3 Mei 2006.

[14] Jogiyanto. (2007). Teori Portofolio dan Analisis Investasi. Yogyakarta: BPFE.

[15] Kewal, Suramaya Suci. (2012). Pengaruh Inflasi, Suku Bunga, Kurs \& Pertumbuhan PDB terhadap Indeks Harga Saham Gabunga. (Online) Jurnal Economia. Vol 8 Nomor 1, April 2012.

[16] Little, Ken. (2013) Understanding Dividend Payout Ratio http://stocks.about.com. Diakses 06 November 2013.

[17] Maulidiani, Mely. (2011). Diskusi Kuliah SEM. http://www.scribd.com/doc/76592699/Diskusi-Sem. Diakses 14 Februari 2014.

[18] Ming, Tjia Hwa. (2012). Analisis Beta terhadap Return Saham http://tiaieming.blogspot.com/2012/12/analisis-beta-terhadap-returnsaham.html. Diakses tanggal 21 Februari 2014.

[19] Muhayatsyah, Ali. (2012). Pengaruh Kinerja Keuangan dan Ekonomi Makro Terhadap Return dan Beta Saham Syariah Pada Perusahaan yang Konsisten di Jakarta Islamic Index. Jurnal Hukum Islam dan Ekonomi Vol. 1 No. 2. Desember 2012.

[20] Murti, Wahyu. (2011). Pengaruh Kinerja Keuangan Terhadap Return Saham. Jakarta: Cintya Press.

[21] Mustafa EQ., Zainal dan Tony Wijaya. (2012). Panduan Teknik Statistik SEM \& PLS dengan SPSS AMOS. Yogyakarta: Cahaya Atma Pustaka.

[22] Nazwirman. (2008). Penilaian Harga Saham dengan Price Earnings Ratio (PER): Studi Kasus pada Saham Industri Makanan dan Minuman di Bursa Efek Indonesia. Makara, Sosial Humaniora (Online), Vol. 12 No. 2 Hal. 98-106. http://www.journal.ui.ac.id, Diakses 21 November 2013.

[23] Novelia, Laurent dan Lina Nur Hidayati. (2011). Pengaruh ROA, EPS EVA dan ROE terhadap Return Saham pada Perusahaan Manufaktur yang Terdaftar di BEI Periode 2007-2010. (Online) Vol. 1 Edisi II. https://journal.student.uny.ac.id. Diakses 17 Desember 2013

[24] Pranggana, Amanda dan Winarno. (2011). Pengaruh Faktor Fundamental dan Risiko Sistematik terhadap Harga Saham pada Industri Properti dan Real Estate di Bursa Efek Indonesia Periode 2008-2011 (Online), Vol. 1 Edisi II. http://journal.student.uny.ac.id/ Diakses 17 Desember 2013.

[25] Samsul, Mohamad. (2006). Pasar Modal dan Manajemen Portofolio. Jakarta: Erlangga

[26] Sarwono, Jonathan. Teori http://www.jonathansarwono.info/sem/sem.htm.

[27] Saxena, Atul K. (2013) Determinants of Dividend Payout Ratio Regulated Versus Unregulated Firms. hhtp://www.westga.edu.html Diakses 06 November 2013.

[28] Suganda, Tarsisius Renald. (2011). Analisis Risiko Saham Berdasarkan Beta Akuntansi: Studi Pada Saham Sektor Industri Retail Pedagang Eceran. Jurnal MRA Vo. 1 No. 1 Februari 2011.

[29] Suhartono dan Fadlillah Qudsi. (2009). Portofolio Investasi dan Bursa Efek. Yogyakarta: YKPN

[30] Suseno, Yustiantomo Budi. (2009). Analisis Faktor-faktor yang Mempengaruhi Beta Saham (Studi Kasus Perbandingan Perusahaan Finance dan Manufaktur yang Listing di BEI pada Tahun 2005-2007). Tesis. Semarang: Program Pasca Sarjana Universitas Diponegoro.

[31] Suyanto. (2007). Analisis Pengaruh Nilai Tukar Uang, Suku Bunga dan Inflasi Terhadap Return Saham Sektor Properti di Bursa Efek Jakarta Tahun 2001-2005. Tesis. Semarang: Program Pasca Sarjana Universitas Diponegoro.

[32] Tambunan, Andy Porman. (2010). Menilai Harga Wajar Saham. Jakarta: PT Elex Media Komputindo.

[33] Tandy S, Heryanto, Azwir Nasir dan Yessi Mutia Basri. (2011). Pengaruh Pertumbuhan Penjualan, Ukuran Perusahaan dan Earning per 
Shares Terhadap Beta Saham Perusahaan Konsumsi yang Terdaftar di BEI Tahun 2008-2010. Skripsi. http://repository.unri.ac.id. Diakses 21 November 2013.

[34] Tohiri, Mukharis. (2009). Analisis Pengaruh Rasio Keuangan terhadap Beta Saham Perusahaan di Jakarta Islamic Index (JII). Tesis. Yogyakarta: Program Pasca Sarjana UIN Sunan Kalijaga.

[35] Usman, Mohammad. (2008). Pengaruh Operating Leverge, Financial Leverage, Total Asset Turnover dan Price Earnings Ratio terhadap Beta Saham Perusahaan. (Online). Journal Accounting Business and Management Vol. 15. http://jabm.stie-mce.ac.id . Diakses 30 September 2013.

[36] Utama, Citra Kurnia. (2009). Pengaruh Tingkat Suku Bunga, Tingkat Inflasi, Nilai Tukar Rupiah dengan Dolar Amerika terhadap Risiko
Sistematik. Tesis. Program Pascasarjana Universitas Katolik Indonesia Atma Jaya.

[37] Utomo, Welly. (2007). Analisis Pengaruh Beta dan Varian Return Saham terhadap Return Saham. Tesis. Semarang: Program Pascasarjana Universitas Diponegoro.

[38] Wasik, John. (2013). Column: Smart-Beta Stocks ETF's Focus on Fundamentals. http://www.reuters.com. Diakses 13 November 2013.

[39] WBBA, Amanda dan Wahyu Ario Pratomo. (2013). Analisis Fundamental dan Resiko Sistematik Terhadap Harga Saham Perbankan yang Terdaftar pada Indeks LQ45. (Online), Jurnal Ekonomi dan $\begin{array}{llllr}\text { Keuangan } & \text { Vol. } & 1 & \text { No. } & 3\end{array}$ (jurnal.usu.ac.id/index.php/edk/article/.../3170/153), diakses 24 September 